В рудеральных фитоценозах виды семейства Роасеае обитают на умеренно увлажненных почвах с низким содержанием азота. В лесных и прибрежных фитоценозах с участием злаков почвы отличаются низкой влажностью и средним уровнем трофности. В луговых сообществах значения химических показателей почвенного субстрата варьируют. Во всех исследуемых сообществах определены кислые почвы.

$$
* * *
$$

1. Пробатова Н. С. Семейство мятликовые или злаки - Poaceae Barnh. (Gramineae Juss.) // Coсудистые растения советского Дальнего Востока. Л., 1985. Т. 1. С. 89-382.

2. Олонова М. В. Изучение комплекса Роa glauca (Роасеае) на территории Сибири // Ботан. журн. 2001. Т. 86. № 8. C. 18-27.

3. Морозова К. В. Злаки Карелии. Петрозаводск: изд-во ПетрГУ, 2013. 247 с.

4. Ипатов В. С. Методы описания фитоценоза. СПб.: СПбГУ, 2000. 55 с.

5. Цвелев Н. Н. Определитель сосудистых растений Северо-Западной России (Ленинградская, Псковская и Новгородская области). СПб.: Изд-во СПХФА, 2000. 782 с.

6. Лянгузова И. В., Ярмишко В. Т. Методика описания почв. Краткая классификация лесных почв // Методы изучения лесных сообществ. СПб.: НИИ Химии СПбГУ, 2002. С. 67-73.

7. Аринушкина Е. В. Руководство по химическому анализу почв. М., 1970. 470 с.

8. Тимофеева В. В. Флора малых городов южной Карелии (состав, анализ): Дис. ... канд. биол. наук. Петрозаводск, 2005. $368 \mathrm{c}$.

9. Антипина Г. С. Урбанофлора Карелии. Петрозаводск: Изд-во ПетрГУ, 2002. 150 с.

10. Кравченко А.В. Конспект флоры Карелии. Петрозаводск: Изд-во КарНЦ РАН, 2007. 403 с.

\title{
Романкина М.Ю. \\ Характеристика населения жужелиц (Coleoptera, Carfbidae) пойменных и суходольных лугов Тамбовской области
}

Мичуринский государственный аграрный университет (Россия, Мичуринск)

doi: $10.18411 / \mathrm{j}-30-09-2017-18$

idsp: 000001:lj-30-09-2017-18

\section{Аннотация}

В Тамбовской области в результате антропогенной трансформации, приведшей к изменениям ландшафтов создалась мозаичность природных условий. В результате расчистки леса, сенокошения, выпаса скота, возникли луга суходольные и пойменные. Данные о комплексах видов жужелиц в серии фитоценозов, выделенных в пределах луговых массивов позволили провести различия между суходольными и пойменными лугами, основанные на особенностях гидротермического режима и специфики почвеннорастительных условий.

Ключевые слова: видовой состав, биотопический спектр, жизненная форма, видовое обилие, численное обилие, зоофаги, миксофитофаги.

В результате проведенных исследований видовой состав жужелиц на лугах Тамбовской области представлено 75 видами из 28 родов, 17 триб, что составило 36,8 \% от общего числа собранных видов.

По изучению жужелиц лугов Тамбовской области имеются работы $[3-7 ; 2 ; 8]$. Основным методом сбора материала были почвенные ловушки Барбера [10]. Для определения жуков, фиксированных в 4\% растворе формалина, использовали бинокулярный микроскоп МБС и определительные таблицы имаго жужелиц [1]. Система семейства Carabidae приводится по О.Л. Крыжановскому с соавторами [11].

По биотопическому преферендуму среди комплексов жужелиц лугов можно выделить следующие экологические группы: луговая, лугово-полевая, полевая, луговоболотная, лесная, лесо-болотная, болотная, приводная, степно-полевая и степная. Анализ 
данных показывает, что при формировании населения жужелиц лугов основное значение принадлежит видам групп открытых пространств. Суммарное видовое обилие жужелиц этого комплекса на лугах составило $42,7 \%$, а численное - 61,1\%. Причем на суходольных лугах видовое обилие комплекса жужелиц открытых пространств выше $(62,3 \%)$, чем на пойменных лугах $(36,7 \%)$. Численное обилие жужелиц на лугах было примерно одинаковым $(60,1 \%$ и $62,1 \%$ соответсвенно). Среди видов открытых пространств ведущее место принадлежит лугово-полевой группе. Эта группа включает 20 видов жужелиц, составляющих 26,7\% видового и $38,0 \%$ численного обилия. Основу численности группы на лугах составили Poecilus cupreus, P. versicolor, Amara aenea, A. communis, Curtonotus aulicus, Harpalus affinis. Значение лугово-полевой группы жужелиц по видовому обилию на суходольных лугах выше (37,8 \%), чем в пойменных (22,4\%). Численное обилие жужелиц в суходольных лугах почти в два раза выше чем в пойменных лугах. На долю полевой и луговой групп на территории лугов области приходится 9,3\% и 6,7\% видового обилия соответственно. Численное обилие жужелиц полевой группы $(22,3 \%)$ во много раз превышает численное обилие жужелиц луговой группы. Многочисленными среди полевых видов были Anisodactylus binotatus, A. signatus, Harpalus rufipes. Массовых видов жужелиц среди луговой группы нет. Полевые жужелицы как по видовому, так и численному обилию преобладают на суходольных и пойменных лугах, но значение их на суходольных лугах выше.

В комплексе жужелиц лугов Тамбовской области зарегистрированы степнополевые и степные виды, видовое обилие которых было 6,7\% и 4,4\% соответственно, а численное - незначительное. Эти комплексы жужелиц зарегистрированы только в пределах суходольных лугов ( $11,1 \%$ - видового и $0,3 \%$ - численного обилия).

Второе место в биотопическом спектре занимает лесной комплекс жужелиц $(35,9 \%$ видового и $35,0 \%$ численного обилия). В экологическом спектре лугов по числу видов (15), видовому $(20,0 \%)$ и численному $(30,4 \%)$ обилию преобладает лесная группа жужелиц. Наибольшая численность жужелиц в этой группе зарегистрирована у Pterostichus niger и Pt. melanarius. Обилие лесных жужелиц на суходольных лугах выше (20,0\% - видовое, 38,9\% -численное обилие), чем на пойменных (18,4 \% и 20,9\%). Жужелицы лесо-болотной группы, составляют 10,6\% видового и 2,2\% численного обилия. Доля жужелиц этой группы в пойменных лугах (16,3\% видового и 4,0\% численного обилия) выше, чем в суходольных (4,4\%; 0,6\%). Лесо-болотная группа многочисленна на пойменных лугах (Stomis pumicatus, Pterostichus vernalis, Pt. gracilis, Pt. minor, Pt. nigrita, Pt. strenuus, Platynus assimilis, Oxypselaphus obscurum), видовое обилие жужелиц в этой группе составляет 16,3\%. На суходольных лугах лесо-болотная группа представлена видами Pt. vernalis, P. assimilis, видовое обилие - 4,4\%. Жужелицы болотной группы (Bembidion biguttatum, Pterostichus anthracinus, Agonum versutum, Chlaenius nigricornis, Oodes helopioides) зарегистрированы только в пойменных лугах и составляют $10,2 \%$ видового и $5,1 \%$ численного обилия. Лугово-болотная группа на лугах представлена видами Bembidion articulatum, Agonum muelleri, A. sexpunctatum, A. viduum, A. moestum, Acupalpus meridianus, Badister bullatus, В. unipustulatus. Их видовое обилие равно 10,6 \%, численное - незначительно. Доля жужелиц лугово-болотной группы в пойменных лугах выше $(16,3 \%$ видового, $2,3 \%$ - численного обилия), чем на суходольных. В состав приводной группы жужелиц лугов вошло 2 вида (Bembidion varium, B. dentellum). В общем спектре доля жужелиц этой группы равна 2,7\% видового и $2,6 \%$ численного обилия. В пойменных лугах обилие жужелиц составило 4,1\% видового и $5,6 \%$ численного. На суходольных лугах приводная группа жужелиц не зарегистрирована.

Фауна жужелиц луговых экосистем была проанализирована по составу жизненных форм, классификация которых разработана И.Х. Шаровой [9]. Анализ спектров жизненных форм дает представление о морфо-экологической структуре населения жужелиц позволяет выявить комплекс специфических условий местообитания. Набор жизненных форм жужелиц лугов довольно разнообразен, включает 11 групп, из которых 
8 относятся к классу зоофагов и 3 - к классу миксофитофагов. В классе зоофаги зарегистрировано 49 видов, что составляет 65,4\% видового и $66,3 \%$ численного обилия. Среди зоофагов по видовому обилию преобладают формы из напочвенного и подстилочного ярусов почвы - стратобионты поверхностно-подстилочные (виды родов Bembidion, Agonum, Panagaeus, Chlaenius, Oodes, Badister) и подстилочные (Epaphius, Patrobus, Stomis, Pterostichus, Calathus, Dolichus, Platynus, Oxypselaphus). Из них наибольшее значение на пойменных лугах имеют поверхностно-подстилочные формы (15 видов - 30,6\% видового и $10,9 \%$ численного обилия). Это тесно связано с условиями увлажнения и по мере увеличения сухости почвы происходит снижение числа видов и видового обилия - на суходольных лугах поверхностно-подстилочные формы составляют 6,7\% видового обилия. Численное обиие жужелиц в этой группе было незначительным. На долю жужелиц стратобионты подстилочно-почвенных (виды рода Poecilus и некоторые виды рода Pterostichus) приходится 16,0\% видового и 56,0\% численного обилия. В этой группе велика доля численного обилия $(66,0 \%)$ в пойменных лугах. Видовое обилие составляет 14,3\%. Численное обилие подстилочно-почвенных в суходольных лугах ниже $(47,1 \%)$, а видовое обилие $(20,0 \%)$ выше. Доля жужелиц подстилочно-почвенных на суходольных лугах выше (20,0\%), чем на пойменных $(4,3 \%)$.

Видовое обилие эпигеобионтов ходящих (Calosoma investigator, Carabus cancellatus, C. convexus) и эпигеобионтов летающих (Cylindera germanica) на лугах составило от 1,3\% до 4,0\%. Численное обилие этих видов жужелиц незначительно и их доля в суходольных и пойменных лугах примерно одинаковая. Жужелицы групп подстилочно-трещинные (Microlestes minutulus, Cymindis axillaris) и геобионты бегающе-роющие (Broscus cephalotes) зарегистрированы только в суходольных лугах и характеризуются небольшим видовым (4,4\% и $2,2 \%$ соответсвенно и незначительным численным обилием. Геобионты роющие (Clivina fossor) выявлены только в пойменных лугах и составляют 2,0\% видового и $0,5 \%$ численного обилия.

Среди миксофитофагов (26 видов - 34,6\% видового и 33,7\% численного обилия) на лугах наибольшую численность $(25,3 \%)$ имеют жужелицы из группы геохортобионты гарпалоидные. Видовое обилие жужелиц в этой группе составило 14,6\%. Доля жужелиц этой группы в суходольных лугах выше, чем в пойменных. В состав группы вошли виды Amara aenea, A. communis, A. eurynota, A. famelica, A. ovata, A. similata, A. bifrons, A. ingénua, A. equestris, Curtonotus aulicus, Anisodactylus binotatus, A. signatus, Harpalus pumilus, H. hirtipes, H. latus, H. smaragdinus, H. affinis, H. distinguendus. Второе место среди миксофитофагов занимают жужелицы из группы стратохортобионты (Harpalus griseus, $\mathrm{H}$. rufipes, Ophonus azureus, O. stictus). Общее численное обилие этих жужелиц составило $19,0 \%$. Видовое обилие - 5,3\%. Доля стратохортобионтов по численному обилию в суходольных лугах выше $(31,5 \%)$, чем в пойменных (4,6\%). Видовое обилие жужелиц этой группы в суходольных лугах в 2 раза выше $(9,0 \%)$, чем в пойменных $(4,1 \%)$. На долю стратобионтов-скважников (Amara familiaris, A. brunnea, Acupalpus meridianus) приходится 4,0\% видового обилия. Стратобионты скважники наибольшее значение имеют по видовому обилию в суходольных лугах $(4,4 \%)$. Численное обилие жужелиц этой группы незначительно. В группе стратохортобионты по численности выделяется Harpalus rufipes.

Таким образом, сопоставление экологических групп в биотопическом спектре лугов показало, что наиболее типичны на лугах виды открытых пространств (луговополевые, полевые), доля которых на суходольных лугах выше. В пойменных лугах значение имеет лесной комплекс жужелиц (лесные, лесо-болотные виды) равномерно представленный на лугах. Своеобразие спектра суходольных лугов составляют степнополевые и степные виды.

В спектре жизненных форм преобладают зоофаги. Среди зоофагов по видовому обилию доминируют формы напочвенного и подстилочного ярусов почвы, имеющие 
значение в пойменных лугах, что тесно связано с условиями увлажнения и по мере увеличения сухости почвы происходит снижение их обилия. Среди миксофитофагов на лугах преобладают геохортобионты гарпалоидные, освоившие как среду обитания поверхность почвы и растительность. В меньшей степени на лугах представлены обитатели подстилки и травостоя - стратохортобионты и подстилки - стратобионты.

$$
* * *
$$

1. Крыжановский О.Л. Семейство Carabidae - жужелицы // Определитель насекомых Европейской части СССР. Л., 1965. Ч. 2. С. 29-77.

2. Николаева Н.О., Романкина М. Ю. Видовой состав населения жужелиц заливного луга на окраине г. Мичуринска.II Студенческий вестник: межвузовский сборник статей по итогам научноисследовательской работы студентов. Вып. 2. I сост.: М.А. Микляева,А. Ю. Околелов. Мичуринск: ФГБОУ ВПО «МГПИ», 2011. С. 58-61.

3. Попова А.А., Лошакова О.Н. Структура комплексов жужелиц (Coleoptera, Carabidae) на плантации земляники и суходольном лугу // Материалы научно-практической конференции преподавателей и студентов МГПИ (март, 1999). Мичуринск, 1999. С. 98-99.

4. Романкина М.Ю., Кирякина И.В. Видовой состав и экологическая структура населения жужелиц суходольного луга // Проблемы регионального природопользования и методика преподавания естественных наук в средней школе: материалы II регион. научно-практической студен. конференции. Воронеж, 2000.- С. 51-53.

5. Романкина М.Ю. Эколого-фаунистическая структура населения жужелиц (Coleoptera, Carabidae) суходольных лугов в центре Европейской части России иих роль как биоиндикаторов почвеннорастительных условий // Вестник Челябинского государственного педагогического университета. Челябинск. №2. 2010. С.298-312. // Вестник Челябинского государственного педагогического университета. Челябинск. №2. 2010. С.298-312.

6. Романкина М.Ю. Формирование населения жужелиц (Coleoptera, Carabidae) на суходольных лугах в центре Европейской части России // Проблемы современной биологии: Материалы IV Международной научно-практической конференции (20.04.2012). М.: Издательство журнал «Естественные и технические науки» и издательство «Спутник +» 2012 б. С. 106-113.

7. Романкина М.Ю. Структурная организация населения жужелиц пойменных и суходольных лугов Тамбовской области, как индикатор качества природной среды // Вестник Тамбовского университета. Серия: Естественные и технические науки. Вестник ТГУ, Том 19, вып.5, 2014. С. 1344-1346.

8. Христофорова 3.А., Романкина М.Ю. Эколого-фаунистическая характеристика жужелиц суходольного луга II Студенческий вестник: межвузовский сборник статей по итогам научно-исследовательской работы студентов. Вып. 2. I сост.: М.А. Микляева,А. Ю. Околелов. Мичуринск: ФГБОУ ВПО «МГПИ», 2011. С. 62-66.

9. Шарова И.Х. Жизненные формы жужелиц (Coleoptera, Carabidae). -M., 1981. С. 360.

10. Barber H.S. Traps for cave in habiting Insecta. Journal // Elish. Mitchell. Science Soc. 1931. 46. $259-266$.

11. Kryzhanovskij O.L., Kobak J.A., Kataev J.J., Makarov B.M., Shilenkov V.G., 1995. A Checklist of the Ground-Beetles of Rassia and Adjacent Lands (Insecta, Coleoptera, Carabidae). Sofia-Moskow, 1995. S. 341. 